Int. J. Electrochem. Sci., 16 (2021) Article ID: 210324

International Journal of

ELECTROCHEMICAL

SCIENCE

www.electrochemsci.org

\title{
Preparation of Manganese Dioxide Nanozyme as Catalyst for Electrochemical Sensing of Hydrogen Peroxide
}

\author{
Na Zou ${ }^{1,2, *}$, Xianyong Wei ${ }^{1,3, *}$, Zhimin Zong ${ }^{1}$, Xin Li ${ }^{2}$, Funa Meng ${ }^{2}$, Zhaoxia Wang ${ }^{2}$ \\ ${ }^{1}$ Key Laboratory of Coal Processing and Efficient Utilization, Ministry of Education, China University \\ of Mining \& Technology, Xuzhou 221116, Jiangsu, China \\ ${ }^{2}$ Department of Chemistry and Chemical Engineering, Heze University, Heze 274015, Shandong, \\ China \\ ${ }^{3}$ State Key Laboratory of High-efficiency Coal Utilization and Green Chemical Engineering, Ningxia \\ University, Yinchuan 750021, Ningxia, China \\ *E-mail: wei_xianyong@163.com (X. Wei), zgsdytzn@126.com (N. Zou)
}

doi: $10.20964 / 2021.03 .47$

Received: 5 November 2020 / Accepted: 30 December 2020 / Published: 31 January 2021

The two-dimensional manganese dioxide nanoflakes $\left(\mathrm{MnO}_{2} \mathrm{NFs}\right)$ with peroxidase-like activity was synthesized by a biomineralization method using bovine serum albumin (BSA) as a template. After then $\mathrm{MnO}_{2}$ NFs was hybridized with reduced graphene oxide (rGO) for electrochemical sensing of hydrogen peroxide $\left(\mathrm{H}_{2} \mathrm{O}_{2}\right)$. The composition and structure of $\mathrm{MnO}_{2} \mathrm{NFs}$ were characterized by Energy Dispersive X-ray Spectrometer (EDX) and Transmission Electron Microscope (TEM), and the morphology of hybridized material were characterized by Scanning Electron Microscopy (SEM). Electrochemical experiments showed that the hybridized material exhibited good sensing performance toward the reduction of $\mathrm{H}_{2} \mathrm{O}_{2}$ with broad linear ranges of $20 \mathrm{nM}$ to $5 \mu \mathrm{M}$ and $5 \mu \mathrm{M}$ to $800 \mu \mathrm{M}$. The limit of detection is $14.92 \mathrm{nM}(\mathrm{S} / \mathrm{N}=3)$. The good sensing performance is ascribed to the synergistic effects of the special morphology of $\mathrm{MnO}_{2} \mathrm{NFs}$ and good conductivity of the reduced graphene oxide (rGO). The proposed sensor can be used for monitoring the $\mathrm{H}_{2} \mathrm{O}_{2}$ content in real biological environments with good stability, repeatability and selectivity.

Keywords: $\mathrm{MnO}_{2} \mathrm{NFs}$, enzyme-like, $\mathrm{H}_{2} \mathrm{O}_{2}$ sensing, ultrasensitive

\section{$\underline{\text { FULL TEXT }}$}

(C) 2021 The Authors. Published by ESG (www.electrochemsci.org). This article is an open access article distributed under the terms and conditions of the Creative Commons Attribution license (http://creativecommons.org/licenses/by/4.0/). 